\title{
Characteristics of no-scalpel vasectomy patients in Jakarta,
}

\section{Indonesia [version 1; peer review: 1 approved, 1 approved}

\section{with reservations]}

\author{
Fakhri Rahman (D), Ponco Birowo (D), Akmal Taher, Nur Rasyid (D) \\ Department of Urology, Dr. Cipto Mangunkusumo National General Hospital, Faculty of Medicine, Universitas Indonesia, Central \\ Jakarta, 10430, Indonesia
}

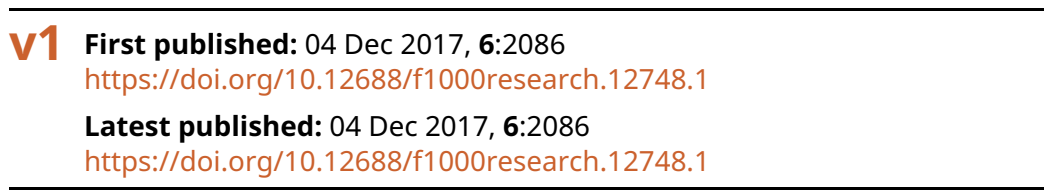

\section{Abstract}

Background: This study aims to learn the demographic and surgical characteristics of patients who underwent no-scalpel vasectomy in Indonesia and to compare patient's demographic characteristics before and after legal pronouncement/fatwa issued by Indonesia Ulema Council in July 2012.

Methods: This is a retrospective study that collected data from the vasectomy medical records of patients who underwent no-scalpel vasectomy between January 2010 and May 2017. A total of 1497 patients were included in this study.

Results: The study found that patients' age of $40-49$ years old (42.8\%), wives' age of $\geq 35$ years old (65.0\%), having three children (34.3\%), being Moslem (85.8\%), high school graduated for patients $(32.3 \%)$ and junior high school graduated for patients' wives (25.7\%), casual laborer $(40.7 \%)$, and guided by family planning program officer $(40.6 \%)$ were the most frequent characteristics found in patients undergoing noscalpel vasectomy. There was a significant difference in certain characteristics before and after fatwa issuance, namely wives' age, number of children, religion, patients' and wives' educational background and the person who guided patients to undergo vasectomy procedure. All no-scalpel vasectomy procedures were done using "Dr. Li's three finger technique" with local infiltration anesthesia; the median length of procedure was 10 (7 - 90) minutes. This study also found that surgeon felt that more than $95 \%$ patients were easy to perform no-scalpel vasectomy procedure and this procedure had low complication rate.

Conclusions: Even though there were significant proportional difference in some characteristics, this study considers that the fatwa was not the only factor that affected patients' choice of no-scalpel vasectomy.

\section{Keywords}

characteristics, no-scalpel vasectomy

Open Peer Review
Approval Status
System, Charlottesville, USA
2. Dominick Shattuck, Georgetown
University's Institute for Reproductive Health,
Washington, USA
Any reports and responses or comments on the
article can be found at the end of the article.


Corresponding author: Nur Rasyid (nur.rasyid@gmail.com)

Author roles: Rahman F: Data Curation, Formal Analysis, Methodology, Writing - Original Draft Preparation; Birowo P: Writing - Review \& Editing; Taher A: Supervision; Rasyid N: Conceptualization, Supervision

Competing interests: No competing interests were disclosed.

Grant information: The author(s) declared that no grants were involved in supporting this work.

Copyright: @ 2017 Rahman F et al. This is an open access article distributed under the terms of the Creative Commons Attribution License, which permits unrestricted use, distribution, and reproduction in any medium, provided the original work is properly cited. Data associated with the article are available under the terms of the Creative Commons Zero "No rights reserved" data waiver (CC0 1.0 Public domain dedication).

How to cite this article: Rahman F, Birowo P, Taher A and Rasyid N. Characteristics of no-scalpel vasectomy patients in Jakarta, Indonesia [version 1; peer review: 1 approved, 1 approved with reservations] F1000Research 2017, 6:2086

https://doi.org/10.12688/f1000research.12748.1

First published: 04 Dec 2017, 6:2086 https://doi.org/10.12688/f1000research.12748.1 


\section{Introduction}

Even though maternal mortality ratio has decreased since 1990, maternal death due to pregnancy- and childbirth-related complications remains a major problem, especially in developing regions ${ }^{1}$. Through Sustainable Development Goals, a continuation of Millennium Development Goals, the United Nations attempted to develop a framework to fight global problems; one of them is maternal mortality ${ }^{2}$.

Family planning programs, which were first intended to reduce the growth of the population, could reduce maternity death through contraceptive services to prevent unintended and high risk pregnancy, such as being too young or old, having too many pregnancies, or having too short an interval between pregnancies. There are several contraception methods that may involve men or women separately. In Indonesia, women still have the major role as contraception users; data from the Indonesian Health Profile 2014 showed that $49.67 \%$ of female users used hormonal injection as their contraception method ${ }^{3}$.

Vasectomy, one contraception method, is considered the safest and most inexpensive option for male sterilization, and no-scalpel vasectomy is preferred due to its shorter operative time and lower complication rate compared to traditional surgery ${ }^{4-6}$. However, only $0.21 \%$ prefer vasectomy to their contraception method in Indonesia ${ }^{3}$. Indonesia, the largest Moslem country, is very influenced by Islam culture, and there are still controversies regarding the use of vasectomy as a contraception method among Moslems. In July 2012, Indonesia Ulema Council (Majelis Ulama Indonesia; MUI), an institution that accommodates ulema or Moslem scholars to guide and nurture Moslems in Indonesia, issued a legal pronouncement/fatwa regarding vasectomy from haram/forbidden into halal/permissible, partly due to success of recanalization/ vasectomy reversal ${ }^{7}$. Even though the fatwa still receives many controversies from other Moslem institutions in Indonesia, it might gradually change an individual's perception regarding vasectomy.

Currently, there is no data regarding demographic characteristics of patients that have undergone no-scalpel vasectomy in Indonesia. Such data could be helpful for the government to plan and evaluate family planning programs, specifically for vasectomy services. Therefore, this study aims to learn the demographic and surgical characteristics of patients who underwent no-scalpel vasectomy in Indonesia. This study also intends to investigate patient demographic characteristics before and after the fatwa issuance.

\section{Methods}

This study protocol received ethical approval from the Faculty of Medicine, Universitas Indonesia Ethical Committee (290/UN2.F1/ ETIK/2017). The data are owned by The Indonesian Association for Secure Contraception (Perkumpulan Kontrasepsi Mantap Indonesia; PKMI) and were approved for use in this study by PKMI.

\section{Data collection}

This is a retrospective observational study. The data was collected from Profamilia Clinic run by PKMI, which is based in Central Jakarta City, DKI Jakarta Province, Indonesia. PKMI is a private professional association focusing on secure contraception. Data are owned by PKMI and collected from patients under the knowledge that the data may be used for future research.

Variables studied in this study were as follows: Patients' and their wives' age; number of children; youngest child's age; religion; patients' and their wives' educational background; patients' occupation; person who guided patients to undergo vasectomy; patient's payment method and patients' surgical characteristics. All variables were collected from the vasectomy medical records of patients who underwent vasectomy between January 2010 and May 2017. The medical record was designed by PKMI. Patients' age was classified according to Indonesia Demographic and Health Survey 2012: Male module (Survei Demografi dan Kesehatan 2012 Modul Pria) ${ }^{8}$. On the other hand, patients' wife age was classified according to high risk maternal age ${ }^{9}$. Indonesia vasectomy guidelines ${ }^{10}$ state that participants must have at least two living children or if patients have only two living children, both children must be older than two years old to undergo vasectomy. Therefore, this study also presented the number of patients who had two children with one of them still under two years of age. All other variables were classified based on vasectomy medical record ${ }^{10}$.

\section{Data analysis}

The data were presented in a descriptive, analytical method. Categorical data were presented by absolute value and its frequency (percentage). Numerical data were presented the mean and standard deviation if the data had normal distribution, and the median and range if the data did not have normal distribution. Any missing data was accounted for and presented in this study. Analytical statistics was used to compare patients' demographic characteristics before and after the fatwa issuance; Chi-squared or Fisher's test was also utilized to compare qualitative variables. Data merging was done if the data did not meet Chi-squared requirements. $P$-value less than 0.05 was considered statistically significant. All of analysis were done using SPSS v. 23.

\section{Results}

There were a total of 1,497 no scalpel vasectomy procedures conducted between January 2010 and May 2017. Demographic characteristics of patients could be seen in Table 1. Most of the patients $(97.4 \%)$ were paid through the governmental program.

From 368 patients who had two children, only 25 patients had a child younger than 2 years old. Among the 1,497 patients undergoing no scalpel vasectomy, there were only 989 (66.1\%) procedure reports found. All patients had infiltration with $2 \%$ lidocaine as an anesthesia technique, without any premedication, and had "Dr. Li's three finger technique" as a surgical technique to perform 
Table 1. Demographic characteristics of patients undergoing no-scalpel vasectomy in Jakarta, between January 2010 and May 2017. July 2012 is when the fatwa was issued.

\begin{tabular}{|c|c|c|c|c|}
\hline Characteristic & Total & $\begin{array}{l}\text { Before } \\
\text { July } 2012\end{array}$ & $\begin{array}{c}\text { After } \\
\text { July } 2012\end{array}$ & $\boldsymbol{P}^{*}$ \\
\hline $\mathbf{N}$ & 1497 & 742 & 755 & \\
\hline $\begin{array}{l}\text { Patient's origin } \\
\text { Central Jakarta } \\
\text { North Jakarta } \\
\text { East Jakarta } \\
\text { South Jakarta } \\
\text { West Jakarta } \\
\text { Kepulauan Seribu } \\
\text { Outside Jakarta } \\
\text { Unknown }\end{array}$ & $\begin{array}{l}517(34.5) \\
285(19) \\
365(24.4) \\
96(6.4) \\
206(13.8) \\
2(0.1) \\
24(1.6) \\
1(0.1)\end{array}$ & $\begin{array}{c}213(28.7) \\
244(32.9) \\
151(20.4) \\
48(6.5) \\
68(9.2) \\
2(0.3) \\
14(1.9) \\
1(0.1)\end{array}$ & $\begin{aligned} 304 & (40.3) \\
41 & (5.4) \\
214 & (28.3) \\
48 & (6.4) \\
138 & (18.3) \\
0 & (0) \\
10 & (1.3) \\
0 & (0)\end{aligned}$ & $<0.001$ \\
\hline Patients' age, years, n (\%) & & & & \\
\hline $\begin{array}{l}<20^{* 1} \\
20-29^{* 1}\end{array}$ & $\begin{array}{c}1(0.1) \\
31(2.1)\end{array}$ & $14(1.9)$ & $18(2.4)$ & \\
\hline $\begin{array}{l}30-39 \\
40-49 \\
50-59 \\
>60 \\
\text { Unknown }\end{array}$ & $\begin{array}{c}382(25.5) \\
641(42.8) \\
367(24.5) \\
72(4.8) \\
3(0.2)\end{array}$ & $\begin{array}{c}181(24.4) \\
327(44.1) \\
176(23.7) \\
42(5.7 \%) \\
2(0.3)\end{array}$ & $\begin{array}{c}201(26.6) \\
314(41.6) \\
191(25.3) \\
30(4.0) \\
1(0.1)\end{array}$ & 0.461 \\
\hline $\begin{array}{l}\text { Wife's age, years, } \mathbf{n}(\%) \\
<20 \\
20-34 \\
\geq 35 \\
\text { Unknown }\end{array}$ & $\begin{array}{c}4(0.3) \\
317(21.2) \\
973(65.0) \\
203(13.6)\end{array}$ & $\begin{array}{c}2(0.3) \\
163(22.0) \\
496(66.8) \\
81(10.9)\end{array}$ & $\begin{array}{c}2(0.3) \\
154(20.4) \\
477(63.2) \\
122(16.2)\end{array}$ & 0.032 \\
\hline $\begin{array}{l}\text { Number of children, } \mathbf{n}(\%) \\
1 \\
2 \\
3 \\
4 \\
5 \\
\geq 6 \\
\text { Unknown }\end{array}$ & $\begin{array}{c}24(1.6) \\
368(24.6) \\
513(34.3) \\
294(19.6) \\
164(11.0) \\
126(8.4) \\
8(0.5)\end{array}$ & $\begin{array}{c}12(1.6) \\
144(19.4) \\
245(33.0) \\
155(20.9) \\
97(13.1) \\
86(11.6) \\
3(0.4)\end{array}$ & $\begin{array}{c}12(1.6) \\
224(29.7) \\
268(35.5) \\
139(18.4) \\
67(8.9) \\
40(5.3) \\
5(0.7)\end{array}$ & $<0.001$ \\
\hline $\begin{array}{l}\text { Youngest child's age, years, median } \\
\text { (minimum - maximum) }\end{array}$ & $5(0-36)$ & & & \\
\hline $\begin{array}{l}\text { Religion, } \mathbf{n}(\%) \\
\text { Islam } \\
\text { Christian } \\
\text { Catholic } \\
\text { Hindu } \\
\text { Buddha } \\
\text { Unknown }\end{array}$ & $\begin{array}{c}1284(85.8) \\
62(4.1) \\
40(2.7) \\
3(0.2) \\
20(1.3) \\
88(5.9)\end{array}$ & $\begin{array}{l}648(87.3) \\
15(2.0) \\
17(2.3) \\
2(0.3) \\
7(0.9) \\
53(7.1)\end{array}$ & $\begin{array}{c}636(84.2) \\
47(6.2) \\
23(3.0) \\
1(0.1) \\
13(1.7) \\
35(4.6)\end{array}$ & $<0.001$ \\
\hline $\begin{array}{l}\text { Patient's education background, } \mathbf{n} \text { (\%) } \\
\text { No formal education } \\
\text { Elementary school } \\
\text { Junior high school } \\
\text { High school } \\
\text { College } \\
\text { Unknown }\end{array}$ & $\begin{array}{c}67(4.5 \%) \\
341(22.8 \%) \\
336(22.4 \%) \\
484(32.3 \%) \\
121(8.1 \%) \\
148(9.9 \%)\end{array}$ & $\begin{array}{c}37(5 \%) \\
188(25.3 \%) \\
155(20.9 \%) \\
246(33.2 \%) \\
44(5.9 \%) \\
72(9.7 \%)\end{array}$ & $\begin{array}{c}30(4.0 \%) \\
153(20.3 \%) \\
181(24.0 \%) \\
238(31.5 \%) \\
77(12 \%) \\
76(10.1 \%)\end{array}$ & 0.009 \\
\hline
\end{tabular}




\begin{tabular}{|c|c|c|c|c|}
\hline Characteristic & Total & $\begin{array}{l}\text { Before } \\
\text { July } 2012\end{array}$ & $\begin{array}{c}\text { After } \\
\text { July } 2012\end{array}$ & $\boldsymbol{P}^{*}$ \\
\hline $\begin{array}{l}\text { Wife's education background, } \mathbf{n} \text { (\%) } \\
\text { No formal education } \\
\text { Elementary school } \\
\text { Junior high school } \\
\text { High school } \\
\text { College } \\
\text { Unknown }\end{array}$ & $\begin{array}{c}78(5.2 \%) \\
373(24.9 \%) \\
384(25.7 \%) \\
368(24.6 \%) \\
86(5.7 \%) \\
208(13.9 \%)\end{array}$ & $\begin{array}{c}42(5.7 \%) \\
214(28.8 \%) \\
179(24.1 \%) \\
186(25.1 \%) \\
31(4.2 \%) \\
90(12.1 \%)\end{array}$ & $\begin{array}{c}36(4.8 \%) \\
159(21.1 \%) \\
205(27.2 \%) \\
182(24.1 \%) \\
55(7.3 \%) \\
118(15.6 \%)\end{array}$ & 0.001 \\
\hline $\begin{array}{l}\text { Patients' occupation, } \mathbf{n} \text { (\%) } \\
\text { Government employees } \\
\text { Private sector employee } \\
\text { Casual laborer } \\
\text { Army or Police } \\
\text { Retired } \\
\text { Businessmen }\end{array}$ & $\begin{array}{c}46(3.1) \\
518(34.6) \\
609(40.7) \\
14(0.9) \\
4(0.3) \\
97(6.5)\end{array}$ & $\begin{array}{c}26(3.5) \\
248(33.4) \\
302(40.7) \\
6(0.8) \\
3(0.4) \\
42(5.7)\end{array}$ & $\begin{array}{c}20(2.6) \\
270(35.8) \\
307(40.7) \\
8(1.1) \\
1(0.1) \\
55(7.3)\end{array}$ & 0.082 \\
\hline Farmer $^{\star 2}$ & $7(0.5)$ & $1(0.1)$ & $7(09)$ & \\
\hline Fishermen ${ }^{\star 2}$ & $1(0.1)$ & & & \\
\hline $\begin{array}{l}\text { Unemployment } \\
\text { Unknown }\end{array}$ & $\begin{array}{c}85(5.7) \\
116(7.7)\end{array}$ & $\begin{array}{l}52(7.0) \\
62(8.4)\end{array}$ & $\begin{array}{l}33(4.4) \\
54(7.2)\end{array}$ & \\
\hline $\begin{array}{l}\text { Source of information/guidance, } \mathbf{n}(\%) \\
\text { Friends or family } \\
\text { Other family planning program participants } \\
\text { Health workers } \\
\text { Family planning program officers } \\
\text { Shaman } \\
\text { Himself } \\
\text { Other } \\
\text { Unknown }\end{array}$ & $\begin{array}{c}97(6.5) \\
74(4.9) \\
15(1.0) \\
608(40.6) \\
3(0.2) \\
31(2.1) \\
11(0.7) \\
658(44.0)\end{array}$ & $\begin{array}{c}45(6.1) \\
48(6.5) \\
7(0.9) \\
423(57.0) \\
0(0) \\
20(2.7) \\
8(1.1) \\
191(25.7)\end{array}$ & $\begin{array}{c}52(6.9) \\
26(3.4) \\
8(1.1) \\
185(24.5) \\
3(0.4) \\
11(1.5) \\
3(0.4) \\
467(61.9)\end{array}$ & $<0.001$ \\
\hline
\end{tabular}

no-scalpel vasectomy. All procedures used simple ligation and excision of a vas segment without using electro-cauterization. Other details of procedure report from patients included in this study are shown in Table 2.

There were a few complications reported by patients following no-scalpel vasectomy, which are presented in Table 2. This study found that no semen analysis was done within 1-3 month after the no-scalpel vasectomy procedure.

\section{Dataset 1. Demographic and surgical characteristics of no-scalpel vasectomy patients}

http://dx.doi.org/10.5256/f1000research.12748.d185669

\section{Discussion}

No-scalpel vasectomy is a vasectomy procedure that is widely used today, due to its advantages over scalpel vasectomy; it is considered the safest and most inexpensive method for male sterilization $^{4-6}$. However, it only contributes to a small percentage of the contraceptive methods used in Indonesia. This might be because the majority of Indonesian men (70.4\%) have never heard about men sterilization, and among men who were aware of male sterilization methods, $77.4 \%$ never considered to undergo sterilization ${ }^{8}$. There were many factors found to affect the selection of vasectomy as a contraception method, such as lack of knowledge and negative attitudes toward vasectomy among patients and providers, education level, age, occupation, number of children, spousal support and social norms ${ }^{11,12}$.

Indonesia is a country with the largest Moslem population in the world. There are still controversies regarding vasectomy procedures among Moslems in Indonesia. However, in July 2012, MUI declared a fatwa changing vasectomy from haram to halal in condition due to success recanalization/vasectomy reversal ${ }^{7}$. This study compared the demographic characteristics of patients who underwent no-scalpel vasectomy before and after MUI's fatwa issuance. This study found no significant difference in patients' age and patients' occupation before and after fatwa issuance. However, there was a significant difference regarding spouses' age, number of 

Table 2. No-scalpel vasectomy procedure
reports for patients in Jakarta, between January 2010 and May 2017.

\begin{tabular}{|c|c|}
\hline Procedure & \\
\hline $\mathbf{N}$ & 989 \\
\hline $\begin{array}{l}\text { Length of procedure time, } \\
\text { minutes, median } \\
\text { (minimum - maximum) }\end{array}$ & $10(7-90)$ \\
\hline $\begin{array}{l}\text { Grasping Vas Deferens, n (\%) } \\
\text { Easy } \\
\text { Difficult } \\
\text { Unknown }\end{array}$ & $\begin{array}{c}938(94.8) \\
35(3.5) \\
16(1.7)\end{array}$ \\
\hline $\begin{array}{l}\text { Scrotal skin puncture, } \mathbf{n}(\%) \\
\text { Easy } \\
\text { Difficult } \\
\text { Unknown }\end{array}$ & $\begin{array}{l}955(96.6) \\
18(1.8) \\
16(1.6)\end{array}$ \\
\hline $\begin{array}{l}\text { Spreading tissue, } \mathbf{n}(\%) \\
\text { Easy } \\
\text { Difficult } \\
\text { Unknown }\end{array}$ & $\begin{array}{c}967(97.8 \%) \\
6(0.6 \%) \\
16(1.6 \%)\end{array}$ \\
\hline $\begin{array}{l}\text { Vas Extraction, } \mathbf{n}(\%) \\
\text { Easy } \\
\text { Difficult } \\
\text { Unknown }\end{array}$ & $\begin{array}{l}945(95.6) \\
28(2.8) \\
16(1.6)\end{array}$ \\
\hline $\begin{array}{l}\text { Type of suture material, } \mathbf{n}(\%) \\
\text { Silk } \\
\text { Cat gut } \\
\text { Unknown }\end{array}$ & $\begin{array}{l}981(99.2) \\
2(0.2) \\
6(0.6)\end{array}$ \\
\hline $\begin{array}{l}\text { Fascia interposition, } \mathbf{n}(\%) \\
\text { Yes } \\
\text { No } \\
\text { Unknown }\end{array}$ & $\begin{array}{c}930(94.0) \\
6(0.6) \\
53(5.4)\end{array}$ \\
\hline Complication & \\
\hline $\begin{array}{l}\text { Edema } \\
\text { Yes } \\
\text { No } \\
\text { Unknown }\end{array}$ & $\begin{array}{c}9(0.6) \\
1423(95.1) \\
65(4.4)\end{array}$ \\
\hline $\begin{array}{l}\text { Pain } \\
\text { Yes } \\
\text { No } \\
\text { Unknown }\end{array}$ & $\begin{array}{c}14(0.9) \\
1418(94.7) \\
65(4.4)\end{array}$ \\
\hline $\begin{array}{l}\text { Ecchymosis } \\
\text { Yes } \\
\text { No } \\
\text { Unknown }\end{array}$ & $\begin{array}{c}1(0.1) \\
1431(95.6) \\
65(4.4)\end{array}$ \\
\hline $\begin{array}{l}\text { Infection } \\
\text { Yes } \\
\text { No } \\
\text { Unknown }\end{array}$ & $\begin{array}{c}2(0.1) \\
1433(95.7) \\
65(4.4)\end{array}$ \\
\hline
\end{tabular}

children, preligion, patients' and spouses' educational background, and the person who guided patients to undergo vasectomy procedure before and after fatwa issuance.

This study found that no-scalpel vasectomy procedure was most common in the age group of 40-49 years old (42.8\%), followed by age group of 30-39 years old $(25.5 \%)$ and $50-59$ years old $(24.5 \%)$. This finding is similar to other studies, which found that most vasectomy users underwent the procedure when they were over 30 years of age, but the largest proportion was at the

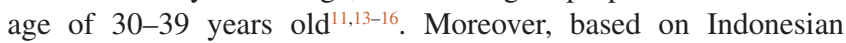
Demographic and Health Survey 2012 (Survei Demografi dan Kesehatan 2012), among patients considering vasectomy, the largest proportion was found at the age of 30-39 years old, followed by $40-49$ years old 9 . Regarding the wife's age, over 35 years old was the most common age of wife of patients undergoing no-scalpel vasectomy procedures. This is explained, since pregnancies over 35 years has a high risk for women. Other studies found the wife's age of over 30 as the age for husbands to undergo vasectomy, while the mid- to late 30 s was considered "typical" for Asian couples ${ }^{11,13,15,17}$. There was significant difference in wife's age before and after fatwa issuance. However, this is most likely due to larger missing data after fatwa issuance, which could be due to poor data collection.

Among no-scalpel vasectomy patients, most of them had three children (34.3\%) when they underwent no-scalpel vasectomy procedure. There were variations regarding the number of children among the patients across geographical regions. Although in general, the vasectomy was performed when the number of children was four or more in some places, in other places two or more children were enough to encourage patients to undergo vasectomy, such in the USA or Iran ${ }^{11-13,15}$. There were significant differences regarding the number of children before and after fatwa issuance. After July 2012, there were higher proportion of patients having two children and lower proportion of patients having three or more children compared to before July 2012. This could be a sign of the success of the family planning program. However, further study is needed to support this hypothesis.

Islam is the most stated religion among patients undergoing no-scalpel vasectomy in Jakarta. This is because Islam is the majority religion in Indonesia. This study found a signficant difference in patients undergoing no-scalpel vasectomy in terms of religion before and after fatwa issuance. Interestingly, however, there were no increased participation of Moslems to undergo noscalpel vasectomy. There was a higher proportion of Christian and Buddhist patients who underwent no-scalpel vasectomy after fatwa issuance compared to before fatwa issuance. However, an increase in the proportions of both religions could not be explained.

This study also found a high proportion of no-scalpel vasectomy patients and their spouses graduated from high school, junior high 
school, and elementary school (patients: $32.3 \%, 22.4 \%$ and $22.8 \%$; wives: $24.6 \%, 25.7 \%$ and $24.9 \%$, respectively). Therefore, this study found that the majority of patients who underwent vasectomy had less than 12 years of education. Other studies showed varied education levels across regions with the majority of patients and their spouses illiterate or had low education levels in developing countries. However, in developed countries, vasectomy was more prevalent in men with high education level ${ }^{16-18}$. There were significant differences in education level for both patients and their spouses before and after July 2012. This might be due to the increased of education participation of Indonesian people, especially at junior high school and college level. This is supported by the presence of the same trend in both patient and wife education background data, which show an increase in the proportion of junior high school and college graduated. However, the government-level data regarding Indonesia's education participation rate are currently unavailable.

Most of the patients (40.6\%) undergoing no-scalpel vasectomy were suggested by family planning program officers to choose no-scalpel vasectomy as their contraception method. Family planning program officers and their cadres have an important role in helping patients to decide on vasectomy ${ }^{19}$. Data from Ghana showed that most patients gained information regarding vasectomy through media and healthcare workers, whereas only small amounts of patients gained the information from family and friends ${ }^{15}$. There was a significant difference before and after July 2012 regarding source of information/guidance who encourages patients to undergo no-scalpel vasectomy. However, this was probably due to a high proportion of missing data.

All no-scalpel vasectomy procedures were performed using "Dr. Li's three finger technique". This technique was developed by Dr. Li Shunqiang and was performed using ringed clamp and dissecting forcep ${ }^{10,20}$. From the procedure report, this study found that doing no-scalpel vasectomy only took a relatively short amount of time (median 10 minutes; range 7-90 minutes). Other studies found a similar short operative time for no-scalpel vasectomy ${ }^{6,21,22}$. The wide range of operating times in this study might be influenced by operator's experience. One study found that high learning curve for no-scalpel vasectomy procedure required $10-15$ operations before being able to perform the procedure perfectly ${ }^{23}$. All the procedures performed on the patients in this study were performed using infiltration as the anesthesia technique. There are several anesthetic techniques beside infiltration, such as combination of infiltration and spermatic cord block and no needle jet anesthesia. One study found that combination of infiltration and spermatic cord block was the best and the most effective method for reducing pain during vasectomy ${ }^{4}$.

This study also found that "Dr. Li's three finger technique" was an easy procedure to conduct. Most operators felt easy in performing the steps of "Dr. Li's three finger technique" in no-scalpel vasectomy procedure. All procedures used ligation and excision (LE) without cautery. Cautery was associated with more rapid progression to severe oligospermia and fewer early vasectomy failure $^{24,25}$. However, cautery has not been adapted yet into standard practice in Indonesia. Silk was the suture material mostly used for vas ligation in this study. There were various suture materials used, such as cotton and cat gut. One study showed that the usage of vicryl increased vasectomy failure three times compared to chromic cat gut. However, until today, there was no study comparing effectiveness of silk, cotton and cat gut $^{20,26}$. Most of procedures used fascial interposition (FI) as an additional step when performing no-scalpel vasectomy in this study. FI can reduce the risk of occlusive failure when performing LE and was associated with decreased time to azoospermia, decreased time to severe oligospermia and reduced failure based on semen analysis ${ }^{22,27}$. The use of combination between LE and FI varied from one country to another. There were several reasons why FI was not performed in South Asian countries, such as technical difficulties, time consuming as it adds 2-4 minutes, and national standard practice didn't include FI as a mandatory step ${ }^{22}$.

This study found only a few complications that occurred during the no-scalpel vasectomy procedures. Another study also found few complications after no-scalpel vasectomy procedures, with an overall rate of $0.32 \%$, consisting of hematoma, bleeding, foreign body granuloma, scrotal pain, epididymitis and sinus formation ${ }^{28}$. However, there was also a probability that patients didn't report their complication or came to another facility, due to long distance, in this study. This study also found that no semen analysis was done after the vasectomy procedures. Based on the standard practice guideline, semen analysis should be done in the first month until the third month after vasectomy has been performed ${ }^{10}$. However, low compliance might be caused by long distance and cost. Other studies reported compliance under $30 \%$, except for one center, in Nepal for semen analysis ${ }^{29}$.

This is the first study that which describes the characteristics of patients undergoing no-scalpel vasectomy in Indonesia. Data in this study could be useful to encourage further studies, to plan and to evaluate programs related to contraception, specifically male sterilization. However, there are also limitations in this study regarding missing data. Some variables had high missing data, such as the data regarding wife's age and sources of information/ guidance. This should encourage health care providers to pay more attention to completeness of data. Such data could be useful for a variety of goals, such as program evaluation.

\section{Conclusion}

Despite its limitations, this study provides a depiction of the characteristics of patients undergoing no-scalpel vasectomy in Jakarta. Even though there were significant proportional difference in some characteristics, this study considers that the fatwa was not the only factor that affects a patient's choice of no-scalpel vasectomy. This study also found that no-scalpel vasectomy was considered an easy procedure to perform and caused minimal complications. 
Data availability

Dataset 1. Demographic and surgical characteristics of no-scalpel vasectomy patients. doi, 10.5256/f1000research.12748.d185669 ${ }^{30}$

\section{Competing interests}

No competing interests were declared.
Grant information

The author(s) declared that no grants were involved in supporting this work.

\section{Acknowledgements}

Authors would like to say thank you to The Indonesian Association for Secure Contraception (Perkumpulan Kontrasepsi Mantap Indonesia / PKMI) for their help in providing data.
1. WHO, UNICEF, UNFPA, et al.: Trends in maternal mortality: 1990 to 2015: estimates by WHO, UNICEF, UNFPA, World Bank Group and the United Nations Population Division. Geneva: WHO Press; 2015.

Reference Source

2. Kumar S, Kumar N, Vivekadhish S: Millennium Development Goals (MDGs) to Sustainable Development Goals (SDGs): addressing unfinished agenda and strengthening sustainable development and partnership. Indian J Community Med. 2016; 41(1): 1-4.

PubMed Abstract | Publisher Full Text | Free Full Text

3. Kementerian Kesehatan: Profil Kesehatan Indonesia 2014 [Internet]. Jakarta. Yudianto, Budijanto D, Hardhana B, Soenardi TA, editors. Kementerian Kesehatan Republik Indonesia. Jakarta: Kementrian Kesehatan Republik Indonesia; 2015. Reference Source

4. Aggarwal H, Chiou RK, Siref LE, et al:: Comparative analysis of pain during anesthesia and no-scalpel vasectomy procedure among three different local anesthetic techniques. Urology. 2009; 74(1): 77-81.

PubMed Abstract | Publisher Full Text

5. Seenu V, Hafiz A: Routine antibiotic prophylaxis is not necessary for no scalpel vasectomy. Int Urol Nephrol. 2005; 37(4): 763-5. PubMed Abstract | Publisher Full Text

6. Cook LA, Pun A, van Vliet $\mathrm{H}$, et al:: Scalpel versus no-scalpel incision for vasectomy. Cochrane Database Syst Rev. 2007; (2): CD004112. PubMed Abstract | Publisher Full Text

7. Muhyiddin: Fatwa MUI tentang vasektomi: tanggapan ulama dan dampaknya terhadap peningkatan medis operasi pria (MOP). Al-Ahkam. 2014; 24(1): 69-92. Publisher Full Text

8. BKKBN, UNFPA: Survey Demografi dan Kesehatan 2012: Modul Pria [Internet]. Jakarta; 2014.

Reference Source

9. Cavazos-rehg PA, Krauss MJ, Spitznagel EL, et al.: HHS Public Access. Matern Child Heal J. 2015; 19(6): 1202-11.

10. PKMI: Panduan pelayanan vasektomi tanpa pisau untuk pelaksana pelayanan 3rd ed. Rasyid N, editor. Jakarta: Perkumpulan Kontrasepsi Mantap Indonesia (PKMI). 2013.

11. Nurlina R: Analisis partisipasi pria sebagai akseptor KB (kondom dan vasektomi) di wilayah kerja Puskesmas Cipanas Kecamatan Cipanas Kabupaten Lebak Provinsi Banten tahun 2011. Universitas Indonesia; 2011. Reference Source

12. Keramat A, Zarei A, Arabi M: Barriers and facilitators affecting vasectomy acceptability (a multi stages study in a sample from north eastern of Iran), 2005-2007. Asia Pacific Fam Med. 2011; 10(1): 5. PubMed Abstract | Publisher Full Text | Free Full Text

13. Shattuck D, Perry B, Packer C, et al.: A Review of 10 Years of Vasectomy Programming and Research in Low-Resource Settings. Glob Heal Sci Pract. 2016; 4(4): 647-60.

PubMed Abstract | Publisher Full Text | Free Full Text

14. Farrokh-eslamlou H, Oshnouei S, Alinejad V: Novel restricted access to vasectomy in Iran: Addressing changing trends in vasectomy clients characteristics over 16years in NorthWestern Iran. Contraception. 2015; 92(5): 488-93.

PubMed Abstract | Publisher Full Text

15. Hotaling JM, Patel DP, Brant WO, et al.: Demographic and socio-economic differences between men seeking infertility evaluation and those seeking surgical sterilization: from the National Survey of Family Growth. BJU Int. 2015; 116(2): 288-92.

PubMed Abstract | Publisher Full Text
16. Owusu-asubonteng G, Dassah ET, Odoi AT, et al.: Trend, client profile and surgical features of vasectomy in Ghana. Eur J Contracept Reprod Heal Care. 2012; 17(3): 229-36.

PubMed Abstract | Publisher Full Text

17. Garg M, Dalela D, Dalela D, et al:: Short-term morbidity following No-Scalpel Vasectomy: an assessment of clients' perceptions by novel postcard system. Urologia. 2014; 81(3): 177-81.

PubMed Abstract | Publisher Full Text

18. Pile JM, Barone MA: Demographics of Vasectomy--USA and International. Urol Clin North Am. 2009; 36(3): 295-305.

PubMed Abstract | Publisher Full Text

19. Anderson JE, Jamieson DJ, Warner L, et al:: Contraceptive sterilization among married adults: national data on who chooses vasectomy and tuba sterilization. Contraception. 2012; 85(6): 552-7.

PubMed Abstract | Publisher Full Text

20. EngenderHealth: No-scalpel vasectomy: an illustrated guide for surgeon. 3rd ed. New Jersey: EngenderHealth; 2004. Reference Source

21. Dachlan I, Rochadi S: Lama tindakan dan kejadian komplikasi pada vasektom tanpa pisau dibandingkan dengan vasektomi metoda standar. Berkala limu Kedokteran. 1999; 31(4): 243-7.

Reference Source

22. Labrecque M, Dufresne $C$, Barone MA, et al:: Vasectomy surgical techniques: a systematic review. BMC Med. 2004; 2: 21. PubMed Abstract | Publisher Full Text | Free Full Text

23. Ardiana $\mathrm{Y}$, Januraga PP, Karmaya M, et al.: Faktor yang berperan pada penerimaan kontrasepsi vasektomi di Kabupaten Lombok Timur (Factors that contribute to the acceptance of vasectomy as contraception option in East Lombok Regency. Public Heal Prev Med Arch. 2015; 3(2): 218-23. Reference Source

24. Sokal D, Irsula B, Chen-mok M, et al.: A comparison of vas occlusion techniques: cautery more effective than ligation and excision with fascial interposition. BMC Urol. 2004; 4(1): 12.

PubMed Abstract | Publisher Full Text | Free Full Text

25. Barone MA, Irsula B, Chen-mok M, et al.: Effectiveness of vasectomy using cautery. BMC Urol. 2004; 4: 10.

PubMed Abstract | Publisher Full Text | Free Full Text

26. Kotwal S, Sundaram SK, Rangaiah CS, et al.: Does the type of suture material used for ligation of the vas deferens affect vasectomy success? Eur $J$ Contracept Reprod Heal Care. 2008; 13(1): 25-30. PubMed Abstract | Publisher Full Text

27. Sokal D, Irsula B, Hays M, et al:: Vasectomy by ligation and excision, with or without fascial interposition: a randomized controlled trial [ISRCTN77781689]. BMC med. 2004; 2: 6 .

PubMed Abstract | Publisher Full Text | Free Full Text

28. Bhuyan K, Ali I, Sarma G, et al.: No Scalpel Vasectomy (NSV) with Ligation and Excision: A Single Centre Experience. Indian J Surg. 2015; 77(Suppl 3): 1038-40.

PubMed Abstract | Publisher Full Text | Free Full Text

29. Labrecque M, Pile J, Sokal D, et al:: Vasectomy surgical techniques in South and South East Asia. BMC Urol. 2005; 5: 10 PubMed Abstract | Publisher Full Text | Free Full Text

30. Rahman F, Birowo P, Taher A, et al:: Dataset 1 in: Characteristics of no-scalpe vasectomy patients in Jakarta, Indonesia. F1000Research. 2017. Data Source 


\section{Open Peer Review}

\section{Current Peer Review Status:}

\section{Version 1}

Reviewer Report 12 February 2018

https://doi.org/10.5256/f1000research.13813.r30098

(C) 2018 Shattuck D. This is an open access peer review report distributed under the terms of the Creative Commons Attribution License, which permits unrestricted use, distribution, and reproduction in any medium, provided the original work is properly cited.

\section{Dominick Shattuck}

Georgetown University's Institute for Reproductive Health, Washington, DC, USA

Although this article has many merits, the presentation and organization of the authors ideas and work render it insufficient for indexing at this time. Unfortunately, the title and the content do not match one another. Additionally, traditional research paper structure is not followed.

This paper should be held from being indexed until the structural and editorial modifications are completed, reviewed and approved.

The title of this paper suggests that it is simply a demographic summary of users in J, Indonesia. Upon reading the abstract, another research question, the impact of Fatwa, which would be very interesting to look at comes into play. Then throughout the paper, the authors move from the Fatwa to the demographics to other analyses. this makes for a very disjointed article that is challenging for the readers to follow.

Other structural issues arise, as information about the methodology is spread around the paper and the results are have no clear flow to them. The attached PDF provides detailed comments and specific locations where the authors must revisit the writing and structure of the paper.

Please click here to see the annotated PDF.

Is the work clearly and accurately presented and does it cite the current literature? Partly

Is the study design appropriate and is the work technically sound? Partly

Are sufficient details of methods and analysis provided to allow replication by others? Partly 
If applicable, is the statistical analysis and its interpretation appropriate?

Yes

Are all the source data underlying the results available to ensure full reproducibility? Yes

Are the conclusions drawn adequately supported by the results?

No

Competing Interests: No competing interests were disclosed.

Reviewer Expertise: Men's Reproductive Health

I confirm that I have read this submission and believe that I have an appropriate level of expertise to confirm that it is of an acceptable scientific standard, however I have significant reservations, as outlined above.

Reviewer Report 12 December 2017

https://doi.org/10.5256/f1000research.13813.r28655

(C) 2017 Smith R. This is an open access peer review report distributed under the terms of the Creative Commons Attribution License, which permits unrestricted use, distribution, and reproduction in any medium, provided the original work is properly cited.

\section{Ryan P. Smith}

Department of Urology, University of Virginia Health System, Charlottesville, VA, USA

This is an interesting manuscript which captures some of the barriers in Indonesia preventing widespread adoption of vasectomy. The science is sound and the commentary interesting; however, in its current state, the article requires grammatical review and correction prior to publication. There are errors throughout the text beginning in the abstract. The other clinical comment is that the author's report a guideline suggesting semen analysis be performed 1 month following the procedure, this is not the case for all guidelines (AUA suggests 8-16 weeks).

Is the work clearly and accurately presented and does it cite the current literature? Partly

Is the study design appropriate and is the work technically sound?

Yes

Are sufficient details of methods and analysis provided to allow replication by others? Yes

If applicable, is the statistical analysis and its interpretation appropriate? 
Are all the source data underlying the results available to ensure full reproducibility? Yes

Are the conclusions drawn adequately supported by the results?

Yes

Competing Interests: No competing interests were disclosed.

I confirm that I have read this submission and believe that I have an appropriate level of expertise to confirm that it is of an acceptable scientific standard.

The benefits of publishing with F1000Research:

- Your article is published within days, with no editorial bias

- You can publish traditional articles, null/negative results, case reports, data notes and more

- The peer review process is transparent and collaborative

- Your article is indexed in PubMed after passing peer review

- Dedicated customer support at every stage

For pre-submission enquiries, contact research@f1000.com

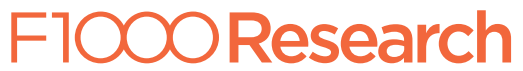

